\title{
A RATIONALE FROM J. S. MILL \\ FOR THE FREE SPEECH CLAUSE
}

\section{INTRODUCTION}

My purpose here is to defend a simple if unpopular thesis. I assume that the Free Speech Clause of the First Amendment has an appropriate range of applicability. The scope of the First Amendment should be determined by the broadest range of purposes or values that can coherently be thought to underlie the Free Speech Clause. Where free speech values are not significantly implicated by any given expression or conduct, the expression is not entitled to protection under the Free Speech Clause. The distinction between expression that is not protected and expression to be accorded limited free speech protection is often not difficult to recognize. When properly drawn, this distinction should expedite the sound resolution of many otherwise problematic free speech cases.

The unpopularity of this argument flows from its incompatibility with two schools of thought. The first would substitute "expression" for "speech," and considers tolerance, pluralism, and diversity to be ultimate goods. It therefore detects speech, and free speech issues, in the most curious of contexts. This school flirts with constitutionalizing libertarianism in an outer sphere of general social conduct in order, it is alleged, more securely to protect the

R. George Wright is Bigelow Fellow and Instructor in Law, The Law School, The University of Chicago.

(c) 1986 by The University of Chicago. All rights reserved.

0-226-46438-5/86/1985-0092\$01.00 
inner sphere of genuine speech. The second, opposing school, of less current practical influence but with unquestioned intellectual credentials, would limit the protection of the Free Speech Clause to a few selected free speech values. Both schools impose unnecessary costs in establishing free speech values.

"Speech" for free speech purposes is not an unproblematic concept in all contexts. It is simultaneously broader and narrower than speech in its literal sense of the spoken word. Free speech values may conflict in a given case, tugging a given instance of expression simultaneously toward or away from recognition as "speech." The approach offered here, however, aims at increased analytical simplicity while preserving the possibility of vigorous application of the Free Speech Clause within its proper and legitimate sphere.

\section{Free Speech Values}

Were we able to ask the drafters of the First Amendment, "Now, when you refer to freedom of speech, do you mean to include, say, commercial nude dancing as a form of speech?" the answer, one suspects, would square poorly with current judicial decisions. But the possibility remains that the drafters chose the open-textured term "speech" just so that we, of a later generation, could include such activities within its purview.

It seems evident that " $[w]$ e know very little of the precise intentions of the framers and ratifiers of the speech and press clauses of the first amendment." Under these circumstances, one approach that might set constitutional theory on a sound jurisprudential basis would be to turn to the classic texts in defense of First Amendment activities for guidance in delimiting the concept of speech; Socrates, John Milton, Locke, Hume, and John Stuart Mill would be obvious sources. We should be disturbed if the classic philosophical exponents of freedom of thought and discussion cannot be fairly enlisted in support of our contemporary free speech case law.

This course, however, is rarely taken directly or explicitly, both because there is ample free speech case law precedent, and because it can hardly be claimed that someone like Mill, however titanic his stature, influenced the drafters of the First Amendment. Moreover, the classic texts are themselves not without difficulties of interpre-

I Ollman v. Evans, 750 F.2d 970, 996 (D.C. Cir. 1984) (en banc) (Bork, J., concurring). 
tation. The reader may therefore wish to interpret "Millian" values as referring simply to all coherently defensible values particularly underlying the Free Speech Clause.

There is at least a fair consensus as to the major contemporary and historical candidates for free speech values or underlying purposes. One broad formulation refers to: " 1 . The development of the faculties of the individual; 2 . The happiness to be derived from engaging in the activity; 3 . The provision of a safety valve for society; and, 4. The discovery and spread of political truth."2 Another frequently cited broad formulation holds: ${ }^{3}$

Maintenance of a system of free expression is necessary (1) as a method of assuring individual self-fulfilment, (2) as a means of attaining the truth, (3) as a method of securing participation by the members of the society in social, including political, decision-making, and (4) as a means of maintaining the balance between stability and change in the society.

Other relatively inclusive formulations of First Amendment or, more specifically, free speech values include those of Professor Stone, who cites the "search for truth," meaningful participation in self-government, and individual "self-fulfillment," and perhaps Chaffee, who refers to both an "individual interest" in "the need of many men to express their opinions on matters vital to them if life is to be worth living, and a social interest in the attainment of truth, so that the country may not only adopt the wisest course of action but carry it out in the wisest way."

Before such broader formulations can be adopted, they must survive the critique of those who have taken any of a variety of narrower views of free speech, and they must have their own internal ambiguities resolved. What will be left in the end is a set of considerations with some surprising implications that I shall refer

\footnotetext{
${ }^{2}$ Bork, Neutral Principles and Some First Amendment Problems, 47 Ind. L.J. 1, 24-25 (1971)(reformulating for purposes of critique the doctrine of Justice Brandeis expressed in Whitney v. California, 274 U.S. 357, 375 (1927)).

${ }^{3}$ Emerson, Toward a General Theory of the First Amendment 3 (1966). See also Bloustein, The Origin, Validity, and Interrelationships of the Political Values Served by Freedom of Expression, 33 Rutgers L. Rev. 372, 373 (1981); Baker, Scope of the First Amendment Freedom of Speech, 25 UCLA L. Rev. 964, 990-91 (1978).

+ Stone, Content Regulation and the First Amendment, 25 Wm. \& Mary L. Rev. 189, 193 (1983).

${ }^{5}$ Chaffee, Free Speech in the United States 33 (1967).
} 
to as Millian values. ${ }^{6}$ To fail to implicate Millian values in some respect is, in that respect, not to be speech at all for free speech purposes.

Three of the most eminent contemporary American scholars who have sought to limit the scope of coverage of the free speech clause have been Alexander Meiklejohn, ${ }^{7}$ Alexander Bickel, ${ }^{8}$ and Robert Bork. ${ }^{9}$ Professor Meiklejohn's distinction between speech implicating the public welfare and speech implicating merely private goods ${ }^{10}$ is perhaps elastic enough to encompass most of what would be considered protected speech under the broader free speech value conceptions. ${ }^{11}$ But to the extent that for Meiklejohn the touchstone of free speech coverage is speech bearing on "issues with which voters have to deal,"12 Meiklejohn's theory is either unduly narrow or misleadingly phrased.

An exclusive concern with issues that we must or may address as voters, expansive as such a category may be, does not seem a felicitous way of capturing what we recognize intuitively as at least one among other free speech values: "[o]ur personal growth. . .intellectual, emotional, aesthetic, professional, vocational, civic, and

\footnotetext{
${ }^{6}$ The term "Millian values" is used for convenience, but the concept draws its strength as well from the writings of the consensually acknowledged classic champions of liberty of inquiry, thought, and discussion, dating from Socrates' Apologia.

${ }^{7}$ See, e.g., A. Meiklejohn, Political Freedom 26-27, 79-80 (1965).

${ }^{8}$ See Bickel, The Morality of Consent 61-75 (1975).

${ }^{9}$ See Bork, note 2 supra, at 23-25. Ronald Dworkin's approach is difficult to classify. I Ie suggests that the "strongest arguments" ordinarily marshaled in free speech cases-a right to listen to argument or to an equal voice in the political process-are not implicated in most pornography cases. Divorkin, A Matter of Principle 335 (1985). He finds "the literature celebrating freedom of speech and press" to be unpromising in justifying a reluctance to censor in the context of pornography. Id. at 336. Dworkin goes on to support a "rightsbased," as opposed to a "goals-based," approach to pornography. Dworkin's argument is that, even if pornography in its various forms imposes long-term net costs on the community, censorship is wrong where it violates an egalitarian "right of moral independence." Ile ultimately concludes "that the right to moral independence, if it is a genuine right, requires a permissive legal attitude toward the consumption of pornography in private." Id. at 358 . Dworkin's argument is not addressed to a particularly American or constitutional context, so it is unclear whether he wants to protect most private consumption of pornography by expanding the Free Speech and Press Clauses or by calling into play substantive due process "privacy" rights or even the Equal Protection Clause.

${ }^{10}$ See A. Meiklejohn, Free Speech and Its Relation to Self-Government 94 (1948).

${ }^{11}$ See Meiklejohn, The First Amendment Is an Absolute, in 1961 Supreme Court Review $245,262-63$.

12 Meiklejohn, note 10 supra, at 93-94.
} 
moral." ${ }^{13}$ While it is far from true that everything implicating our emotional growth, for example, or every expression of emotionality implicates free speech values, certainly the category of personal development ${ }^{14}$ is useful in accounting for why a given expression counts as speech or as protected speech. ${ }^{15}$

Alexander Bickel may also be taken to have restricted the broad free speech value formulations when, in modifying Chaffee's formulation, ${ }^{16}$ he confines the scope of the "social" interest to "the interest in the successful operation of the political process." 17 The political can obviously be defined in narrower or broader terms, and conceptions of what is required successfully to operate a constitutional government vary in breadth. ${ }^{18}$ Paradoxically, what is required to operate the political process successfully probably itself depends on the scope of constitutional protection accorded to speech, so Bickel's formulation may be of limited value. If the political process is thought of narrowly, Bickel's formulation is arbitrarily underinclusive, in that civic-minded persons would, as civic-minded persons, tend to care about and wish to express publicly their opinions on "nonpolitical" matters as much as on "political" concerns. ${ }^{19}$

\footnotetext{
${ }^{13}$ Bloustein, note 3 stupra, at 373.
}

it This formulation raises the unsolved problem of whether a system of free speech, or meaningful free speech, requires the affirmative availability, perhaps by government provision, of open opportunities for education, travel, employment, social class interaction, and such.

15. It should be said in partial defense of Meiklejohn's "voter-issue" formulation that it properly includes a portion of what Professor Baker refers to as "solitary" uses of speech, e.g., recording, cataloging, outlining, and writing notes to oneself. See Baker, note 3 supra, at 993. Recording and organizing privately one's thoughts on political issues would be protected by both Meiklejohn and Baker, even if the recorded and organized thoughts are not intended for any direct subsequent communication. But certainly not all private acts of expression, or self-definition qualify as speceh, with or without the presence of an audience. One can certainly help define the kind of person one is by riding horses and chopping wood by hand at one's ranch or by consuming particular products, but such acts are not ordinary speech. Contra id. at 994.

${ }^{16}$ See note 5 stpra and accompanying text.

17 Bickel, note 8 supra, at 62.

${ }^{18}$ See Wellington, On Freedom of Expression, 88 Yale L.J. J105, 1112 (1979).

19 The Supreme Court has properly observed that "[e]ven though political speech is entitled to the fullest possible measure of constitutional protection, there are a host of other communications that command the same respect. An assertion that 'Jesus Saves,' that 'Abortion is Murder,' that every woman has the 'Right to Choose,' or that 'Alcohol Kills,' may have a claim to a constitutional exemption . . . that is just as strong as 'Robert Vincent-City Council.' " Members of the City Council v. Taxpayers for Vincent, 104 S.Ct. 2118, 2135 (1984). 
In focusing attention on "explicitly and predominantly political speech, ${ }^{20}$ Bork notes: ${ }^{21}$

The First Amendment indicates that there is something special about speech. We would know that much even without a first amendment, for the entire structure of the Constitution creates a representative democracy, a form of government that would be meaningless without freedom to discuss government and its policies. Freedom for political speech could and should be inferred even if there were no first amendment.

The problem with proceeding thus to confine the scope of the Free Speech Clause is, of course, that this interpretation assumes the Clause's redundancy. While it is certainly possible to argue that the drafters inserted this express protection of political speech merely for reasons of expediency, and not genuinely to amend the Constitution, it is at least equally plausible to suggest that the Free Speech Clause was intended to add something meaningful and that the drafters could well have inserted the qualifier "political" had they meant to so confine the Clause.

Narrow formulations of the scope of and values underlying the Free Speech Clause tend, therefore, to be unduly arbitrary. But this does not mean that the broader formulations of free speech values are unproblematic. Writers such as Martin Redish ${ }^{22}$ have explicitly recognized that what is variously referred to as the value of self-realization, or development, of "self-fulfillment," or autonomy, conceals an ambiguity. ${ }^{23}$ For convenience, this ambiguity will be referred to in terms of autonomy $y_{1}$ and autonomy . Autonomy $_{1}$, which can safely be regarded as a Millian value and is at least arguably defensible as a coherent element of distinctive free speech

\footnotetext{
${ }^{20}$ Bork, note 2 supra, at 26.

${ }^{21} I d$. at 23.

${ }^{22}$ See Redish, The Value of Free Speech, 130 U. Pa. L. Rev. 591, 593 (1982).

${ }^{23}$ Cf. Schauer, Free Speech: A Philosophical Inquiry 56-58 (1982) (not acknowledging a broader and narrower sense of autonomy but rejecting autonomy as a value underlying a distinctive free speech principle). It should be noted that, while Schauer does not recognize even autonomy ${ }_{1}$ or self-realization in the narrow sense as an element of a distinctive free speech principle, this will make no significant difference to the argument that follows. One may conclude that Schauer either underplays the direct and substantial connection between autonomy ${ }_{1}$ and free speech or else that he is precisely on target. Whichever, the analysis of the case law areas below should be unaffected. See $i d$. at 56 . The ambiguity at issue is illustrated by Emerson's use of the phrase "the affirmation of self." Emerson, note 3 supra, at 5 , and by Scanlon's use of "autonomy" in Scanlon, A Theory of Freedom of Expression, 1 Phil. \& Pub. Affairs 204 (1972).
} 
values, is connected with self-realization in the sense utilized by Mill and draws on the developmental dynamic that is described by writers as diverse as Aristotle and Hegel. This sense of autonomy or self-realization is associated with what Isaiah Berlin has referred to as "positive liberty." $2+$

Autonomy $y_{2}$, or autonomy in the broader sense, has no essential reference to progress, growth, development, or cultivation of one's "higher powers" and is associated more with simply doing as one likes, generally, or with an absence of socially imposed restraint on one's actions and choices. Autonomy, $y_{2}$ or Berlin's "negative liberty," however valuable it may be, is simply too broadly conceived to support a free speech principle above and beyond a general libertarianism. ${ }^{25}$ Then, too, it will be a rare case indeed in which suppression of the freedom of speech of one group does not simultaneously advance the broad "negative liberty" or autonomy ${ }_{2}$ of another, perhaps larger, group. Autonomy ${ }_{2}$ may therefore be at most of limited usefulness in deciding free speech cases or in deciding what is to count as speech.

Of course, even the theorists subscribing to a broader conception of free speech values have occasionally been subject to criticism for excessively restrictive categorization. Professor Tribe has warned that ${ }^{26}$

[h]owever tempting it may be to resist governmental claims for restricting speech by retreating to an artificially narrowed zone and then defending it without limit, any such course is likely in

\footnotetext{
${ }^{24}$ See Berlin, Two Concepts of Liberty, in Four Essays on Liberty 118, 122-31 (1969). But $c f$. MacCallum, Negative and Positive Freedom, 76 Phil. Rev. 321 (1967) (critically placing Berlin's negative versus positive freedom distinction in proper perspective). See also Bay, The Structure of Freedom (1958); F. Oppenheim, Dimensions of Freedom (1961).

${ }^{25}$ While Mill could, with some qualifications, be classified in at least certain respects as a conduct libertarian, his defense of freedom of "thought and discussion" has much more to do with "flourishing" than with any value associated more broadly with "doing as one likes." In any event, Schauer's dismissal of autonomy as a distinctive First Amendment value is at least as cogent when confined to autonomy ${ }_{2}$. Schauer was on this score anticipated by Robert Bork, who argued that "the development of individual faculties and the achievement of pleasure ... do not distinguish speech from any other activity. An individual may develop his faculties or derive pleasure from trading on the stock market." Bork, note 2 supra, at 25 . Again, the case law argument below does not depend on whether one perceives a special relationship between autonomy $y_{1}$ and free speech, or at least a closer relationship than between autonomy $y_{2}$ and free speech. For a critique of Bork's approach, see Wellington, note 18 supra, at 1120-21. But see Yudof, In Search of a Free Speech Principle, 78 Nw. U.L. Rev. $1139,1348-49$ (1983).
}

${ }^{26}$ See Tribe, American Constitutional Law 579 \& id. n.25 (1978). 
the end to sacrifice too much to strategic maneuver: the claims for suppression will persist, and the defense will be no stronger for having withdrawn to arbitrarily constricted territory.

The trick, of course, is to tell artificial from principled constriction, and it will be argued here that the "Millian values" help us to do so.

In the meantime, it should be recognized that artificially expanding the zone of protected speech beyond that justified by the principles and purposes underlying freedom of speech may disserve those values and impose costs in other ways. Strategically, it is not true that the free speech "army" cannot overextend its position. ${ }^{27}$ It is certainly plausible to argue, as against Tribe, that a refusal to trivialize or debase the Free Speech Clause by extending its application beyond the bounds of its coherent, identifiable purposes helps to enhance and dignify the invocation of the Clause within the full extent of its legitimate scope. If we wish to honor its intrinsic importance, we do so by supporting free speech principles intensively, on every appropriate occasion.

\section{Millian Values and THE ReQuiremient OF A SOCIAL IDEA}

The recognizable, distinctive values or purposes underlying a free speech principle, tied together as Millian values, impose certain requirements on what is to count as speech. In terms of Millian values, for something to be speech it must embody or convey a more or less discernible idea, doctrine, conception, or argument of a social nature, where "social" is understood to include broadly political, religious, ethical, and cultural concerns. For language or gesture or conduct to be speech, it must carry implications beyond the speaker's individual and immediate circumstances. Speech must communicate; it must be, at least potentially, socially "fertile," and not socially sterile or exclusively ego-referential.

Speech, certainly, can be almost purely factual and empirical or normative and evaluative, or informal, or false, or internally inconsistent, or pernicious, or irresponsible; it can go unheard or even be intended for an audience of only the speaker. What it cannot be is

${ }^{27}$ Cf. Schauer, note 23 supra, at 134-35 ("[t]he broader the scope of the right, the more likely it is to be weaker, largely because widening the scope increases the likelihood of conflict with other interests, some of which may be equally or more important"). 
patently sterile, without implication for our collective arrangements and institutions, broadly understood. Self-servingness is not definitive, though; self-serving speech in a marketplace may well not be protected speech, but self-serving speech about the marketplace probably is.

Generalizations about putative speech in particular contexts, such as commercial speech or, as discussed below, in the context of nude dancing or other entertainment, or disorderly conduct arrests, should only be drawn inductively by examining a run of individual cases, judicially decided on a case-by-case basis. The stakes involved-the risks of either trivializing the guarantee or of suppressing legitimate speech-are so high that conclusively presuming putative speech in any particular social context to be or not to be First Amendment speech seems ill advised.

While speech can be vague, or equivocal, or metaphorical, or guarded, or aesopic, this does not mean that the presence of speech depends on the efforts, or successful efforts, of an intended audience, bystanders, or third parties. A verbalization may causally provoke or incite action or inspire thought, speech, or action in others without being speech. A glimpse of a starving child may inspire an ethical debate or change a foreign policy without the child's presence being speech, just as a flower placed in a crannied wall may inspire the poet without speaking or amounting to speech. If one has no significant social message to impart, however confused or apparently foolish or inarticulate or ill formed, the creativity of the listener cannot constitute one's words as speech in this sense. If one has sent a social message, however, even if none was received, or if an entirely different message was received, one has engaged in speech, even if imperfectly.

If talk or conduct does not rise to the level of speech, symbolic or otherwise, this does not mean that such talk or conduct is without practical, statutory, or even constitutional protection. If talk is genuinely or even widely perceived as sterile, there may be little incentive for a government to expend resources in suppressing it.

Even where such incentives exist, other constitutional safeguards apart from the Free Speech Clause may come into play. These may include, beyond due process, ${ }^{28}$ the Free Exercise of Religion Clause, the Equal Protection Clause, the right to vote, the right to

${ }^{28}$ See Meiklejohn, note 7 supra, at 79. 
travel, free assembly and the right to petition, as well as freedoms of association and privacy. ${ }^{29}$ Whatever the constitutional concept, there may be some comfort to be secured from the strong historical tendency of dictatorial regimes to suppress on the ground of alleged harmfulness, or falsity, or unorthodoxy, or as blasphemous, or reactionary, none of which denies the presence of a social idea. Selective enforcement problems are minimized because potential oppressors cannot resist the temptation to label opposing ideas as bad social ideas, thereby admitting that they are some sort of social ideas, and thereby giving the game away.

The reasons for placing these restrictions on the concept of speech reflect the nature of Millian values. Mill's defense of the regime of free speech or, more particularly, of liberty of thought and discussion, was informed not by an undifferentiated libertarianism but by a vision of the progressive enlightened development of a society. Victorian progressives such as Mill were perhaps not so sanguine as to believe that humanity's "prospects of creating a rational and enlightened civilization [were] virtually unlimited," 30 but it is clear that Mill's thinking is not adequately reflected by focusing on a condition of "negative liberty" or on a mere absence of restraint. The end is social progress through individual character development. Without suggesting, of course, that good character should generally be legally enforced, Mill believed that character could be better or worse, higher or lower, and his approach to free speech is inseparable from this assumption.

Mill indeed presupposes a "prior ideal of excellence for human beings further realized by allowing liberty of action and thought." 31 This is reflected in Mill's estimation not of mere idiosyncrasy of speech and behavior" but of "individual growth" ${ }^{33}$ and the "due study and preparation" 34 typically required therefor.

${ }^{29}$ The freedom of the press may be added, if it is thought that this protection of the printed word rests on a different base than freedom of speech.

${ }^{30}$ Emerson, note 3 supra, at 14.

${ }^{31}$ Ladenson, A Philosophy of Free Expression and Its Constitutional Implications 152 (1983).

${ }^{32} I d$. at 150 ("it is . . . a non sequitur to hold that someone who opposes conforming to custom merely as custom must also believe that people should be encouraged to be idiosyncratic simply for the sake of being idiosyncratic").

${ }^{33}$ See Scanlon, Freedom of Expression and Categories of Expression, 40 U. Pitt L. Rer: 473, 483 (1974) (Mill's focus on "true belief and individual growth"; concern for "fostering the development of better (more independent and inquiring) individuals").

${ }^{34}$ Mill, On Liberty 33 (D. Spitz ed. 1975). 
Mill recognizes that not all forms and instances of speech in the literal sense significantly implicate the values and aims underlying freedom of speech. For example, "[t]he scope of Mill's defense of freedom of expression does not cover the dissemination of information, whether true or false, about a person's private life which has no bearing on the scientific, moral, political, religious, and social issues with which he is concerned." 35

Outside the context of his narrow discussion of free speech, but with implications for current free speech issues, Mill observed unhesitatingly that ${ }^{36}$

there are many acts which, being directly injurious only to the agents themselves, ought not to be legally interdicted, but which, if done publicly, are a violation of good manners, and coming thus within the category of offenses against others, may rightly be prohibited. Of this kind are offenses against decency; on which it is unnecessary to dwell.

This is plainly some distance from the late twentieth century free speech jurisprudence that fashionably, if ultimately incoherently, rejects ethical skepticism while settling for an ethical relativism in which one man's indecency is another man's lyric. It also reinforces the necessity for some sort of social idea for protected speech to be present. For Mill, the indecent is, at least sometimes, not only recognizable and is not simply to be shunned as a matter of unconstrained moral preference, but it is also subject to authoritative legal prohibition.

Even where the issue is not susceptibility to prohibition, Mill is not reluctant to distinguish greater and lesser value on grounds other than mere subjective preference. He unselfconsciously asserts that "[i]t may be better to be a John Knox than an Alicibiades, ${ }^{37}$ but it is better to be a Pericles than either; nor would a Pericles, if we

\footnotetext{
${ }^{35}$ Ten, Mill on Liberty 136 (1980).

${ }^{36}$ Mill, note 34 supra, at 91 . See also Ten, note 35 supra, at 106-07; Honderich, 'On Liberty' and Morality-Dependent Harms, 30 Pol. Studies 504-11 (1983). A computer research session suggests that this interesting passage has been quoted only once in recent reported American jurisprudence, and that, appropriately, in dissent. See In re Excelsior Pictures Corp. v. Regents of the University of the States, 3 N.Y.2d 237, 256, (1957) (Burke, J., dissenting). But of. Solzhenitsyn, A World Split Apart, in East and West 50-51 (1980) (reference to "destructive and irresponsible freedom" being granted "boundless scope").

${ }^{37}$ For evidence of Alcibiades' less than sterling character, see Thucydides, The Peloponnesian War 456, 565, 570, 585-86 (R. Warner trans. 1954).
} 
had one in these days, be without anything good which belonged to John Knox." ${ }^{38}$

This, again, is to suggest not that Mill advocated the legal proscription of all that he considered decadent or depraved but merely that there can be no Millian reasons for barring any legal action against that which does not implicate Millian values. Within the sphere of liberty of thought and discussion, Mill is concerned essentially with that which rises to the level of "doctrine," as when he asserts at his most radical that "there ought to exist the fullest liberty of professing and discussion, as a matter of ethical conviction, any doctrine, however immoral it may be considered." 39

For speech in a literal sense to be speech in a protectable, First Amendment sense, though, it must rise to the level of recognizable "doctrine" or of factual assertion or evaluative "opinion" that may in at least some sense be either true or false. This much is clear even from Mill's famous recapitulation of his arguments for liberty of thought and discussion, where he iterates his arguments on infallibility, on the likelihood of partial truth, and on the necessity of vigorous contest to promote vital, as opposed to thoughtless, merely prejudiced belief. ${ }^{40}$ If the putative speech cannot be envisioned as some sort of direct, if minor, contribution to a social or intellectual debate continuing over time, in which there is perhaps a consensus or an array of contesting schools of thought that now approach, now recede from the truth, Millian values are not significantly implicated.

We resist this clear understanding of Mill largely on the assumption that Mill, like many of us, must have subscribed to a sort of nonjudgmental, nonhierarchical general libertarianism. ${ }^{41}$ But this is

\footnotetext{
${ }^{38}$ Mill, note 34 supra, at 59. See also Mill, Utilitarianism 12-13 (Sher ed. 1977) ("no intelligent human being would consent to be a fool . . . even though they should be persuaded that the fool is better satisfied with his lot than they are with theirs").

${ }^{39}$ Mill, note 34 supra, at 17 n.2.

40 Id. at 50 .

+1 It should be clear at this point that any claim that a broad conduct libertarianism underlies and informs the Free Speech Clause is illogical on its own terms, obviously historically anachronistic, contrary to Millian logic, language, and assumptions, and currently inconsistent with a vast panoply of widely accepted paternalistic statutes and judicial decisions, none of which is commonly thought by libertarian opponents to be in logical tension with the Free Speech Clause. Certainly, a broadly libertarian society, however conceived, would by definition proscribe at least certain kinds of restraints on speech, but it remains unclear why liberty of speech must be more central to a libertarian society, or receive greater
} 
inconsistent not only with Mill's arguments and their underlying premises but also with the unmistakable tone or flavor of Mill's language throughout On Liberty. Mill insists on the capacity for "being improved" as a prerequisite to the regime of free speech. ${ }^{42}$ He appeals "to the permanent interests of man as a progressive being." ${ }^{43} \mathrm{His}$ emphasis is on not merely thinking for oneself but also thinking for oneself "with due study and preparation." ${ }^{44} \mathrm{He}$ approves Humboldt's exaltation of "the highest and most harmonious development of [humanity's] powers to a complete and consistent whole" ${ }^{25}$ as the dictate of reason. Choosing one's "plan of life" calls for "observation to see, reasoning and judgment to foresee, activity to gather materials for decision, discrimination to decide, and . . . firmness and self-control to hold to [one's] deliberate decision." $" 6$

Mill refers without embarrassment to "human excellence"47 and goes on to specify that "individuality is the same thing with development." $\mathrm{He}$ is careful to link eccentricity with "strength of character" 49 and to observe that "the amount of eccentricity in a society has generally been proportional to the amount of genius, mental vigor, and moral courage it contained." 50 The ultimate aim remains "cultivation of higher nature." 1

This is not to suggest that only that which is universally recog-

protection, than liberty in plainly nonspeech commercial market transactions, or in child raising and family relations, or in education, or physical movement. In a word, just as the Due Process Clause does not enact Mr. Spencer's Social Statics, the Free Speech Clause does not enact Mr. Nozick's Anarchy, State and Utopia. $C f$. Commonwealth v. Kautz, 491 A.2d 864, 865 (Pa. 1985) (citing Mill's principle of "liberty of tastes and pursuits" and declining to adhere to it in the context of mandatory motorcycle helmets). But $f f$. Linmark Associates, Inc. v. Township of Willingboro, 431 U.S. 85, 96 (1977) (rejecting paternalistic elements of ordinance restricting the flow of housing market information).

${ }^{42}$ Mill, note 34 supra, at 11 .

${ }^{43} I d$. at 12 .

44 Id. at 33 .

45 Id. at 54.

${ }^{+6} I d$. at 56 . None of this is to suggest, of course, that Mill would seek to suppress the speech of those who disagree with the worthiness of Millian values or with any particular conception of their realization.

${ }^{47}$ Id. at 59 .

${ }^{+8} I d$. at 60 .

49 Id. at 63.

${ }^{\text {so }}$ Ibid.

st Id. at 64 . 
nized as decent and uplifting can be entitled to special protection. ${ }^{52}$ The point is merely to elaborate on Millian values, in the absence of which there is no point in according special constitutional protection to a given instance of expression.

It is only the prestige and convenience of Mill's elaborate theory that suggests focusing on Mill and "Millian values." One could, as well, imaginatively resurrect Socrates in the role of constitutional arbiter, to the same end.

It is occasionally suggested that a linkage between the Free Speech Clause and Millian or other values is illegitimate and not textually warranted. William Van Alstyne has said: ${ }^{53}$

The first amendment does not link the protection it provides with any particular objective and may, accordingly, be deemed to operate without regard to anyone's view of how well the speech it protects may or may not serve such an objective. The second amendment expressly links the protection it provides with a stated objective ... and might, therefore, be deemed to operate only insofar as the right it protects . . . can be shown to be connected with that objective.

The problem is that, if we try to remain agnostic about the aims, purposes, or values underlying the Free Speech Clause, there is no reliable, nonarbitrary guide for inclusion or exclusion as "speech." Literalism fails us, since a Morse Code message or sign language may plainly implicate First Amendment values without being speech in a literal sense. ${ }^{54}$ Can something be "symbolic" speech?"

\footnotetext{
52 See, e.g., Pring v. Penthouse Int'l, Ltd., 695 F.2d 438, 443 (8th Cir. 1982), cert. denied, 462 U.S. 1132 (1983). See also Fraser v. Bethel School Dist. No. 403, 755 F.2d 1356 (9th Cir.) cert. granted, 106 S.Ct. $56(1985)$, in which the court confessed that: "[w]e fear that if school officials had the unbridled discretion to apply a standard as subjective and elusive as 'indecency' in controlling the speech of high school students, it would increase the risk of cementing white, middle-class standards for determining what is acceptable and proper speech and behavior in our public schools. Language that may be considered 'indecent' in one segment of our heterogeneous society may be common, household usage in another." Id. at 1363. What the public schools may have overlooked in their rush toward standardlessness along with the Ninth Circuit, aside from the utility of the Equal Protection Clause, is that one defends the decency or propriety of one's language not by claiming that it is common in one's own ethnic or other group to speak or act as one did but by claiming that one's language gave no gratuitous, unnecessary offense to significant numbers of likely hearers from other ethnic or class groups.

${ }^{53}$ Van Alstyne, A Graphic Review of the Free Speech Clause, 70 Cal. L. Rev. 107, 112 n.13 (1982).

${ }^{54}$ See Hart, The Concept of Law 124, 126 (1961) on the logic and practical necessity of recourse to underlying purposes. This need could not be dispensed with merely by the framers' omission of a prefatory statement of purposes in the text of the Amendment itself.

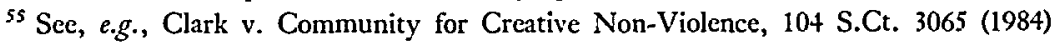


Recourse to the purposes of the Free Speech Clause, as recognized by one or more drafters or by other persons, is necessary in order to decide.

Bearing the Millian values in mind not only permits the principled resolution of free speech cases but also permits, in many instances, their more expeditious and less logically tortuous resolution as well. The complexity of the Supreme Court's treatment, in various contexts, of "low value" speech, meriting some, but only limited, free speech protection, has been described by Professor Stone. ${ }^{56}$ At least some "low value" speech is, in the absence of any significant implication of Millian values, actually "zero value" or, more simply, nonspeech, meriting no Free Speech Clause protection at all. 57

(prohibition of demonstrators from sleeping in Lafayette Park); Spence v. Washington, 418 U.S. 405 (1974) (attachment of peace symbol to flag); Tinker v. Des Moines School Dist., 393 U.S. 503 (1969) (wearing black armband in school); United States v. O'Brien, 391 U.S. 367 (1968) (draft card-burning case). In the recent case of Monroe v. State Court, 739 F.2d 568 (11th Cir. 1984), a flag-burning case, the court held that, if there is an "intent to convey a particularized message . . . and in the surrounding circumstances the likelihood was great that the message would be understood by those who viewed it . . , the activity falls within the scope of the first and fourteenth amendments.' " $I d$. at 570 (quoting Spence, 418 U.S. at $410-11$ ). While it is disheartening to learn that to speak unclearly or over the heads of one's audience is to forfeit free speech protection, and while it is not clear that just any kind of "particularized message" will do, the main point is that this requirement is certainly not drawn from the text of the First Amendment, even by fair inference.

"56 See Stone, note 4 supra, at 194-96. See also Stone, Restrictions of Speech because of Its Content: The Peculiar Case of Subject-Matter Restrictions, 46 U. Chi. L. Rev. 81 (1978).

${ }^{57}$ This is not to suggest, of course, that no close case will appear, or that interesting problems cannot be devised in Millian analysis. Consider the actual, if perhaps unlitigated, case of a sticker reading, in full, "the invasion of Nicaragua." By itself, the sticker conveys no social idea nor otherwise implicates Millian values. It is therefore not "speech" at all. But consider that the sticker is red, and assume that it is designed to be not easily removed once applied. Apparently, the only use for the sticker is an illegal one: to be affixed just below the word "Stop" on a traffic sign. The aim of an ordinance flatly prohibiting the manufacture of such a sticker would be to narrowly effectuate reasonable time, place, and manner restrictions. But the effect of prohibition may be just that. It is certainly not obvious precisely what tests to impose on putative speech that does not rise to the level of a social idea absent illegality.

Some instances of speech may more deeply implicate Millian values than others, independent of any assessment of the speech's falsity or perniciousness. It may be, for instance, that certain forms or modes of speech, apart from subject matter, tend to more deeply implicate Millian values than others.

Mill suggests that "[a]n opinion that corn-dealers are starvers of the poor, or that private property is robbery, ought to be unmolested when simply circulated through the press, but may justly incur punishment when delivered orally to an excited mob assembled before the house of a corn-dealer, or when handed about among the same mob in the form of a placard." Mill, note 34 supra, at 53. While Mill's emphasis here is on a clear and present danger rule, there is also the suggestion that speech in the form of articles may implicate Millian values more deeply than mass oratory or placards, as a general rule. The general hierarchy seems clear: books, articles, and leaflets may tend to be more precise, richer, more articulate, or 
It is possible that the speech-nonspeech distinction may turn out, eventually, to bear a family resemblance to the doctrine of public issue or public matter speech versus private interest speech as developed by the Supreme Court in several contexts. ${ }^{58}$ Of course, the Court has thus far continued to accord concededly private or personal interest speech some limited measure of Free Speech Clause protection. ${ }^{59}$ The public-private interest speech distinction must be further clarified if it is to be consistently applied in a convincing way. $^{60}$

\section{ENTERTAINMENT AND Millian VAlues}

Entertainment is not necessarily beyond the compass of the Free Speech Clause. Some instances of entertainment, such as protest songs or satiric comedy, clearly tend to implicate Millian values. But many forms of entertainment do not. It is unmistakably the law that even, or especially, in a commercial context, "nude dancing is not without its First Amendment protections from official regulation." ${ }^{\prime \prime}$ While this result has not been univer-

self-incriminating intellectually than placards, slogans, banners, and bumper stickers. The world may be better off to the extent that there is a reasonably social class-neutral legal incentive to publish, rather than to sloganeer. Articulateness is not the sole Millian value, or even the dominant or controlling Millian value, but it is a Millian value.

Frederick Schauer has denied the wisdom of drawing this general qualitative distinction in constitutional terms. His argument is that we are bombarded with so much speech nowadays that, in order to be heard, we must each perhaps speak more offensively, or literally or figuratively raise our voice above the din of other speech to acquire or maintain an audience. See Schauer, Note 23 supra, at 201-02. The general futility of this advice seems clear; one might as well counsel all spectators at a football game to stand up in order to see better.

${ }^{58}$ See e.g., Dun \& Bradstreet, Inc. v. Greenmoss Builders, Inc., 105 S.Ct. 2939 (1985) (commercial defamation case); Connick v. Myers, 461 U.S. 138 (1983) (public employment discharge case). See also Chaffee, note 5 supra, at $6,11,18,19$ (focus on "matters of public interest").

${ }^{s 9}$ See, e.g., Connick, 461 U.S. at 147 ("We do not suggest . . . that Myers' speech, even if not touching upon a matter of public concern, is totally beyond the protection of the First Amendment"). But see Jones v. Memorial Hosp. System, 677 S.W.2d 221, 224 (Tex. Civ. App. 1985) ("The federal courts have declined to require protection of speech on matters solely of personal interest. To be entitled to first amendment protection, speech must relate to matters of 'political, social, or other concern to the community.' ") (quoting Connick, 461 U.S. at 146); Meiklejohn, note 7 supra at 79 ("Private speech, or private interest in speech ... has no claim whatever to the protection of the First Amendment").

${ }^{60}$ Part of the lack of clarity of this distinction, resulting in a very dubious analysis in Greenmoss, is attributable to the near emptiness of the Court's "content, form, and context" test, Connick, 461 U.S. at 147-48, and part to the conceptual ambiguity of "interest." See generally Held, The Public Interest and Individual Interests (1970).

${ }^{61}$ Schad v. Borough of Mount Ephraim, 452 U.S. 61, 66 (1981). 
sally acclaimed, ${ }^{62}$ it seems solidly entrenched. The problem is that not all nonobscene commercial nude dancing, for example, purports to convey a social idea in the relevant sense, nor need Millian values otherwise be significantly implicated. As a result, the courts feel "bound to treat topless dancing as a form of expression which is protected at least to some extent by the first amendment," while recognizing that "few of us would march our sons and daughters off to war' to protect that form of expression." 63

It has been suggested in a broader context, though, that sexually related "speech" "will almost invariably carry an implicit, if not explicit, message in favor of more relaxed sexual mores. . . In our society, the very presence of sexual explicitness in speech seems ideologically significant, without regard to whatever other messages might be intended."

It would seem, however, that advocacy of relaxed sexual mores is something imputed to commercial nude dancing or something invested by the third parties in the concept, rather than a message in any sense sent and received. One clue is that "sexual mores" is obviously broader than the activities encompassed by commercial nude dancing. One might even suspect that the hidden agenda of commercial nude dancing may be not the relaxation of sexual mores but keeping them the way they are so that the customers will be motivated to return and pay to watch again. Then again, there may be no intent, explicit or implicit, in operation other than merely to profit or merely to entertain-diversion for its own sake, rather than to make a point. ${ }^{65}$

${ }^{62}$ See, e.g., Judge Richard Posner's reiterated misgivings in Douglass v. Hustler Magazine, Inc., 769 F.2d 1128, 1141 (7th Cir. 1985) ("Art ... even of the artless sort represented by 'topless' dancing - today enjoys extensive protection in the name of the First Amendment") (contrasting an alternative of protecting only "political" speech); Piarowski v. Illinois Community College Dist. 515, 759 F.2d 625, 628 (7th Cir. 1985) (citing Doran v. Salem Inn, Inc., 422 U.S. 922, 932-34 (1975)); Reed v. Village of Shorewood, 704 F.2d 943, 949-50 (7th Cir. 1983) (contrasting "political" and "cultural" expression) (relying on Chaffee, note 5 supra, at 7-33). See also Bork, note 2 supra, at 27 . But see Wellington, note 18 stupra, at $1115-$ 16. Attempting to distinguish between the political and the cultural, at least in broad senses of the terms, appcars to be profoundly difficult. Nor does Mill give us any reason to do so.

${ }^{63}$ Krueger v. City of Pensacola, 759 F.2d 851, 854 (11th Cir. 1985) (quoting Young v. American Mini Theaters, 427 U.S. 50, 70 (1976)).

of Stone, note 56 supra, at $111-12$. But $c f$. the sexually explicit, but ideologically pointless, language of the "cop abuse" cases discussed infra at notes 99-111 and accompanying text.

6s See, e.g., State v. House, 676 P.2d 892, 896 (1984) (en banc) (Rossman, J., dissenting), aff'd 299 Or. 78, 698 P.2d 951 (1985). It is certainly possible, of course, that requiring merely the conveyance of some social idea, as a necessary and sufficient condition to acquir- 
If the "message" of commercial nude dancing is so shadowy and equivocal, however, it is too attenuated and insubstantial significantly to implicate Millian values. ${ }^{66}$ Further, and more controversially, there is no reason necessarily to assume that the Millian pointlessness of commercial nude dancing must depend on a finding of bad taste, lewdness, indecency, obscenity, or widespread offensiveness. A claim of free speech protection for a given activity may "trivialize"67 the Free Speech Clause because of the Millian pointlessness of the activity, and not because the activity is judged immoral, or harmful, or lewd, or misleading. ${ }^{68}$

In a slightly different context, the Eleventh Circuit recently has detected no advocacy or expression of ideas in connection with nude sunbathing, despite plaintiffs' claim that nude sunbathing "is the practice by which they advocate and communicate their philosophy that the human body is wholesome and that nudity is not indecent." 69 The plaintiffs sought to analogize their situation to that involved in the protected commercial nude dancing cases, but the Eleventh Circuit rejected the argument on the grounds that the nude dancing cases, unlike nude sunbathing, involved "nudity in combination with a protection form of expression." lies in the fact that non-sexually oriented social or recreational

ing at least some free speech protection, would in some contexts generate close questions by setting up incentives for nonspeakers to clothe themselves with some free speech protection by adorning themselves with some minimal speech. If the social idea is not expressed by or integrated into the nude dance routine but is merely "worn about the neck" to ward off constitutional attack, then only the readily severable social idea communication itself should be protected by the Free Speech Clause. There is generally no need to inquire whether the invokers of the Free Speech Clause "really" believe in, or even vaguely understand, their own protected and protective social idea.

66 The assumption that commercial nude dancing is ordinarily sought to be suppressed because of its "content," in the same sense in which a regime might seek to suppress Das Kapital or Mein Kampf because of dislike of or unpopularity of its content, seems doubtful. See Krueger, 759 F.2d at 854.

${ }^{67}$ Highway Tavern Corp. v. McLaughlin, 105 A.D.2d 122, 139, 483 N.Y.S.2d 323, 338 (1984).

${ }^{68}$ Of course, the state is understandably required to show more than mere triviality before obtaining a criminal conviction. See, e.g., State v. Jacobson, 459 So. 2d 1285, 1290 (La. Ct. App. 1984) (obscenity conviction); Erhardt v. State, 468 N.E.2d 224, 225 (Ind. 1984) (vacating 463 N.E.2d 1121 (Ind. Ct. App. 1984)) (public indecency conviction).

${ }^{69}$ South Florida Free Beaches, Inc. v. City of Miami, 734 F.2d 608, 609-10 (11th Cir. 1984). In contrast, a Florida court has recognized a free speech right to beg alms for oneself, despite the presumably limited message content involved. See C.C.B. v. State, 458 So. $2 \mathrm{~d}$ 47, 48 (Fla. Ct. App. 1984).

$70734 \mathrm{~F} .2 \mathrm{~d}$ at 610 . 
dancing is generally not accorded any free speech protection at all, despite the ability of articulate persons to generate plausible "messages," such as antipuritanicalism, that might be imputed to recreational or social dancing. ${ }^{71}$

Sorting these cases out, it appears that the courts attach crucial First Amendment significance to a strict separation of performer and audience. Persons in a group of social dancers are not viewed as performing for themselves or for each other as an audience. Performance dancing, nude or, presumably, otherwise, with an audience, is protected, unlike social dancing, and it does not lose its "expressive," protected quality when associated with nudity. Sunbathing clad, however, is not an otherwise free speech protected activity, and nudity adds or subtracts nothing in the way of free speech protection to the sunbathing. ${ }^{72}$

The cases can probably thus be reconciled. What should not be overlooked, however, is that there is no Millian value-based rationale available to defend the results obtained if it is recognized that the courts often protect putative speech that does not even purport to convey any social idea.

If one turns to the video game free speech cases, one finds that the possible analogy of video game screens to movies is generally downplayed and that video games, at least at the present state of technology, are typically said to fall afoul of the requirement that, to enjoy free speech protection, the entertainment be intended to convey some idea or information. ${ }^{73}$ This is an eminently sensible result from a Millian standpoint and, despite contentions that some video games vaguely inculcate distinctively martial values, should stand until the video screen conveys, in a manner inextricable with

${ }^{71}$ See, e.g., Jarman v. Williams, 753 F.2d 76, 78 (8th Cir. 1985) (assuming that the "message" intended is merely that dancing is not wrong); Kent's Lounge, Inc. v. City of New York, 104 A.D.2d 397, 398, 478 N.Y.S.2d 928, 929 (1984) ("recreational dancing is not a form of speech protected by the First Amendment") (further noting the absence of free speech protection for rollerskating).

${ }^{72}$ Break dancers are therefore advised to gather a discrete, separate audience-an audience of one's fellow break dancers may not suffice; one must argue for their "receptivity" while not taking their turn-and, secondarily, to try to think of some articulable message above and beyond approval of break dancing.

${ }^{73}$ See, e.g., Marshfield Family Skateland, Inc. v. Town of Marshfield, 389 Mass. 436, 450 N.E.2d 605, 609, cert. dismissed, 104 S.Ct. 475 (1983); Caswell v. Licensing Comm'n, 387 Mass. 864, 868, 444 N.E.2d 922, 926-27 (1983); People v. Walker, 135 Mich. App. 267, 275,354 N.W.2d 312, 316-17 (1984), appeal dismissed sub. nom. Walker v. Warren, 106 S.Ct. 32 (1985). 
what is sought to be prohibited, some sort of recognizable social idea.

The idea or information requirement tends to go out the window, however, in other entertainment contexts, such as musical performances. The First Amendment, it has been held, protects the right to produce jazz concerts. ${ }^{7+}$ Similarly, the bands marching in Philadelphia's Mummers Parade, complete with "thematic arrangement," are engaged in "a form of expressive entertainment" protected by the First Amendment. ${ }^{75}$ The problem in focusing on the "expressiveness" or performance aspect of the entertainment is, of course, the determination to ignore the absence of any social idea. Expressive entertainment in the form of juggling, plate balancing, and the swallowing of swords or goldfish cannot be distinguished in principle from the above sorts of performances. If anything is clear about the First Amendment, it is that such activities, however captivating, are simply not speech. ${ }^{76}$

Again, though, these generalizations are subject to some exceptions. One could theoretically employ plate balancing as a medium of social criticism. Since there are substantial risks, potentially, in erroneously deciding free speech cases for or against the speaker, which may be summed as the risks of decadence or loss of purpose versus the risk of suppression, a case-by-case determination process without the aid of specific presumptions seems called for here, even if most cases of plate balancing do or do not turn out to involve speech.

The logic of the entertainment cases is ultimately derived from the now rather quaint "crime magazine" case of Winters v. New York. ${ }^{77}$

\footnotetext{
${ }^{74}$ See Fact Concerts, Inc. v. City of Newport, 626 F.2d 1060, 1063 (1st Cir. 1980), rev'd on other grounds, 453 U.S. 247 (1981).

${ }^{75}$ See Tacynec v. City of Philadelphia, 687 F.2d 793, 796 (3d Cir. 1982), cert. denied, 459 U.S. 1172 (1983).

${ }^{76}$ A somewhat more complex case is presented by Cinevision Corp. v. City of Burbank, 745 F.2d 560 (9th Cir. 1984), cert. denied, 105 S.Ct. 2115 (1985). The court, in a case involving the concert promotion of several rock groups of arguably varying "hardness," indicated that "constitutional safeguards are not applicable only to musical expression that implicates some sort of ideological content." Id. at 569. From a Millian value standpoint, one would at least want to inquire into such matters as life-style endorsements or the contents of song lyrics for the Free Speech Clause to be implicated. Actually, there was some evidence of genuine, easily judicially detected content-based broadly political discrimination in Cintevision. See id. at 573.
}

77333 U.S. 507 (1948). 
The court indicated, in a free press clause context: ${ }^{78}$

We do not accede to appellee's suggestion that the constitutional protection for a free press applies only to the exposition of ideas. The line between the informing and the entertaining is too elusive for the protection of that basic right. Everyone is familiar with instances of propaganda through fiction. What is one man's amusement, teaches another's doctrine.

The Court in Winters was otherwise confident, of course, of its ability reliably to detect the lewd, the indecent, and the absence of social value in a publication. ${ }^{79}$ Its otherwise consistent judicial modesty, however, is appropriate only with respect to recognizable borderline cases. Obviously, propaganda in the guise of fiction is ordinarily protectable speech on any theory. But it is unreasonable to suggest that since there are undeniably borderline cases, it is either impossible or pointless to recognize the substantial numbers of instances in which the absence of any intent to convey a social idea can be fairly and reliably detected.

\section{Profanity and the Abuse of Cops, Meter Maids, AND Civilians: The CONJUNCTION OF CHAPLINSKY AND COHEN}

It may be that the very triviality of much pure entertainment perversely inspires First Amendment protection: If it is socially inconsequential, why permit its suppression? This brings into isue the judicial refusal to defer to the legislative balancing of the benefits and costs associated with the literally pointless prohibited activity. There are a wide variety of cases of allegedly socially pointless "speech" in which the alleged associated harms range from public "pollutant" effects, such as a general coarsening in the tenor of public discourse, to the taking of justified personal offense, to the threat of physical violence. ${ }^{80}$

It must be conceded at the outset that, while the well-known

\footnotetext{
${ }^{78}$ Id. at 510.

${ }^{79} \mathrm{Ibid}$.

${ }^{80}$ See, e.g., Archibald Cox's argument that the expression at issue in Coben imposed social costs in the form of a lowering of the standard of public debate, in Cox, The Role of the Supreme Court in American Government 47-48 (1976).
} 
Coben case $^{81}$ should not be defended in unduly romantic terms, $\mathrm{Co}$ ben was probably correctly decided in Millian value terms. In Coben, a jacket bearing the inscription ${ }^{82}$ "Fuck the Draft" inspired a divided Court to observe that it is "often true that one man's vulgarity is another's lyric"83 and to decline to "indulge the facile assumption that one can forbid particular words without also running a substantial risk of suppressing ideas in the process." ${ }^{84}$ Whether or not an attempt generally to forbid any particular words was ever at issue, the Court in effect constitutionalized protection of the emotive, as opposed to cognitive, force of language. ${ }^{85}$

But the Coben result is defensible as a recognition of a particular phrase, in historical context, that barely made it into the category of "speech" by expressing a remarkably vague social idea about a reasonably clearly specified social phenomenon, the draft. Whether or not "Fuck" would have been speech by itself or not, "Fuck the Draft," in context, probably was. More enthusiastic defenses seem questionable.

It is suggested, for example, that "Resist the Draft" and "Fuck the Draft" do not convey the same meaning, ${ }^{86}$ or that "Fuck the Draft" says it twice as well, ${ }^{87}$ or that the manner of expression in Coben is "more powerful," 88 or that, more generally, "[t]he use of profanity . . . is often an effective means for individuals to convey

${ }^{81}$ Cohen v. California, 403 U.S. 15 (1971).

${ }^{82}$ Evidently, Cohen was not the author of the inscription, and the jacket in question was covered with writing, among which the words "Fuck the Draft" did not particularly stand out. See Farber, Civilizing Public Discourse: An Essay on Professor Bickel, Justice Harlan, and the Enduring Significance of Cohen v. California, 1980 Duke L.J. 283, $286 \& 286$ n.21. These details accord rather poorly with the image of a protester so overwrought with intensity of indignation that he, unlike, say, Henry David Thoreau in Civil Disobedience, could not reasonably be expected to convey this depth of feeling through mere nonprofane speech.

${ }^{83} 403$ U.S. at 25 . Despite its judicial modesty in this respect, the Court remains fully inclined to review judgments that distinguish protected material that "provokes only normal, healthy sexual desires" from material that arouses "morbid" and presumably unhealthy responses. See Brockett v. Spokane Areades, 105 S.Ct. 2794, 2799 (1985).

${ }^{84} 403$ U.S. at 26.

${ }^{85}$ Ibid.

${ }^{86}$ See, e.g., Rutzick, Offensive Language and the Evolution of First Amendment Protection, 9 Harv. C.R.-C.L. L. Rev. 1, 19 n.98 (1974) (quoting Maiman, Speech v. Privacy: Is There a Right Not to Be Spoken To? 67 Nw. U. L. Rev. 153, 189 (1972)).

${ }^{87}$ See Van Alstyne, note 53 supra, at 142.

${ }^{88}$ See Redish, The Content Distinction in First Amendment Analysis, 34 Stan. L. Rev. $113,141(1981)$. 
dramatically otherwise inexpressable emotions." 89 It is pointed out that "[n]ot everyone can be a Daniel Webster."

None of these arguments is without point. Yet each can easily be oversold. Despite its non-McCluhanesque tenor, there is some sense in the observation that "[a] requirement that indecent language be avoided will have its primary effect on the form, rather than the content, of serious communication. There are few, if any thoughts that cannot be expressed by the use of less offensive language." 91 If a surgically neat form-content distinction is impossible, it remains true that the slope connecting the proscribing of Cohen's language in that particular context and banning or regulating Thoreau is not terribly slippery.

The more central problem is that, without projecting our own sentiments into Coben, we simply cannot tell what "Fuck the Draft" means well enough to pass informed judgments as to its power, aptness, or effectiveness. We can, admittedly, dispute at the margins what Thoreau meant in a literal sense. But "Fuck the Draft," while it conveys enough meaning of a social character to cross the line into speech, is not far from a blank sheet of paper. Does it mean, roughly, as C. L. Stevenson might suggest, "I strongly disapprove of the draft," do so as well? Perhaps it means, in alienated fashion, "I strongly disapprove of the draft, but/and I don't care what you think": an entirely different message and one to which we know Thoreau would not have subscribed.

The grounds of the objection are not hinted at. The draft may be abhorrent for a variety of moral reasons or out of practical selfinterest. Obviously, a slogan can say only so much, and it is unreasonable to expect a speaker to pack an expository essay into a slogan, but this only bespeaks the limited communicative value of slogans and the riskiness at best of assuming that a slogan, profane or otherwise, is likely to be particularly apt in expressing deep frustrations. ${ }^{92}$ If we can't tell what Cohen meant at some level of

\footnotetext{
${ }^{89}$ Stone, note 4 supra, at 244.

${ }^{0}$ People v. Callahan, 168 Cal. App. 3d 631, 214 Cal. Rptr. 294, 296 (1985), op. withdrawn, cert. denied, 54 USLW 3484 (Jan. 21, 1986).

${ }^{91}$ FCC v. Pacifica Foundation, 438 U.S. 726, 743 n.18 (1978) (opinion of Stevens, J., joined by Burger, C. J., and Rehnquist, J.). Note that of these three, only Chief Justice Burger was available to joint the dissenters in Cohen.

22 It is interesting to note that Cohen's expression scans well only with moderate-level alleged evil as a target. "Fuck Nazism," or "Fuck Genocide," or "Fuck Slavery," or "Fuck Terrorism" are uninspiring partly because of the abstractness of the institution denounced
} 
detail, how can we know how well his slogan expressed his feelings?

An interesting assumption at work in the defense of Coben is that a person's willingness consciously to violate basic norms of social propriety, etiquette, or concern for the sensibilities of others, including those of some of one's allies, implies that the person must feel more strongly, deeply, or intensely than the rest of us, or than Thoreau did, or than the person himself does on many other subjects.

This is a fallacy, though. Some of us simply have a low threshold of resort to predictably socially offensive behavior, quite apart from the intensity of our "feelings." 93 The feelings of others may simply not be thought to matter much. So even if we are to accord free speech protection to emotions, as opposed to ideas, we must not assume the emotion from the willingness to offend.

Occasionally, the more enthusiastic defenders of Coben discuss social trends and touch on the incentives set up by Coben ${ }^{94}$ One court has observed that "[w]hat is vulgar to one may be lyric to another. . . . Some people spew four-letter words as their common speech such as to devalue its currency; Billingsgate thus becomes commonplace." 95 This sort of argumentation, along with the observation that many words are less shocking now than they used to be, ${ }^{96}$ is curiously reversible in its import. It would seem, all else equal, that the degeneration of language or of the quality of discussion is to be avoided. Any process of having to outbid one's competitors for linguistic shock effect, worked out as a kind of Gresham's

but also because they are immediately recognizable as adolescent-minded trivialization of the evils involved. We would not view them as "effective" or "powerful" statements.

${ }^{93}$ Consider the facial expression of the next person who violates the rules and breaches decorum by playing his radio aloud on the bus. Does he seem to have an unusually intense ' devotion to music that has resulted in the dictates of social propriety being outweighed? Or does he merely look as bored as the rest of us? We must not simply read fervor and commitment into Cohen-type situations.

${ }^{94} 403$ U.S. at 25 . See also Rutzick, note 86 supra, at 20; Bollinger, Free Speech and Intellectual Values, 92 Yale L.J. 438, 470 (1983). If one does not believe that there are longterm, subtle, but significant consequences flowing from this judicial relativism, one need not fear being soon confronted by clear, vigorous, empirical proof to the contrary. We tend to be skeptical that societies decay culturally, but we do recognize this phenomenon writ small, as in the obviously decaying morale of a baseball tcam as it slides toward the cellar.

${ }^{95}$ Callahan, note 90 supra.

${ }^{96}$ Ibid. 
Law among the tokens of language, would similarly seem a bad thing.

Lost amid the relativism of Coben is the obvious point that even if we cannot reliably tell vulgarity from lyric, we can reasonably well predict that what we view as lyric will or will not be found gratuitously offensive by substantial numbers of reasonably tolerant people. Protected speech may be rude or offensive, particularly where the rudeness or offensiveness is inseparable from the message. But elevating or at least maintaining the level or quality of the debate is a Millian value. While not all of us can rise to the level of a Daniel Webster or a Thoreau, this is not what the detractors of Coben would require. The question is whether it would be constitutionally permissible, under the Free Speech Clause, to require an even slightly closer approach to the level of a Daniel Webster than Coben manifests if we are to address the public. The aim is not to ban any usage per se or to disenfranchise the inarticulate but to require of all speakers a certain minimum, easily attained level of respect for the feelings of many among the audience. It has been suggested that ${ }^{97}$

offensiveness is often an important part of a speaker's message. Use of offensive language reveals the existence of something offensive and ugly, whether in the situation described by the speaker or in the speaker's mind itself. In either event, the language reveals an important though unpleasant truth about the world. Suppressing this language violates a cardinal principle of a free society, that truths are better confronted than repressed. . . . We cannot expect to have, nor should we require, true civility in discourse until we achieve civility in society.

Of course, an assassination attempt on a popular political figure also may reveal an important truth, but the issue is whether the price is worth paying. By the time of Cohen's speech, the "truth" about the draft - that it was profoundly immoral, let us say-had already been "said" and was already generally "known." From contrary speech, we also already generally "knew" the "truth" that the draft was a fine thing. What we actually learned from Cohen's speech was mostly about Cohen, and, as we have seen, Cohen's speech told us very little about him or the state of his mind at all.

${ }^{97}$ Farber, note 82 supra, at 302. 
What we learned probably qualifies as neither particularly unpleasant nor important.

At the time of Cohen's speech, no one doubted the controversiality of the draft or the willingness of many persons to speak indecorously. Nor is there, ultimately, any clear reason to hold a minimal civility in public discourse hostage until such a time as we have achieved civility in society. The former has not been shown to be an impediment to achieving the latter, and it may perhaps be its prerequisite. If the two forms of civility are causally independent, why not enjoy the former while we await the arrival of the latter? At a minimum, it is unclear why we are bound by the Free Speech Clause never to accord the effect of a given speech on the level of discussion any weight at all, even where the effect on the level of debate is undisputed.

Perhaps on the theory, though, that grievances are better aired than compulsorily bowdlerized, a recent Louisiana Court of Appeals case has, on the strength of Coben, given free speech protection to the display on a pickup truck bumper of a sticker reading "Fuck Charles Foti, Jr." Mr. Foti was a local sheriff. The court displayed no great interest in attempting to distinguish Cohen, perhaps on the grounds that, while a jacket may be discreetly taken off and folded up, there may be a felt necessity to park a truck in a given space regardless of the presence of, say, a school yard or playground in the vicinity.

Actually, it may be that the only way of distinguishing the case is to take the direct route. Except under rare circumstances not discussed in the Foti opinion itself, "Fuck Charles Foti, Jr." does not convey even a rudimentary social idea, even if Mr. Foti is relatively well known locally. Whether such an expression is printed on a bumper sticker, inscribed on a jacket, or chiseled in marble on the author's front lawn, it is, in most circumstances, simply too diffuse and "open" to significantly implicate Millian values, even granting that it rises in significance above mere random lettering. Unlike "Fuck the Draft," it does not even psychologically tie in with or trigger thoughts on any particular social issue. ${ }^{99}$ Attempts at selec-

${ }^{98}$ See State v. Meyers, 462 So. 2d 227, 227 (La. Ct. App. 1984).

${ }^{99}$ Apparently, though, there are limits to Cohen's power to sanctify the emotive. In a recent case, the Seventh Circuit announced that it was unable to locate "any authority for the proposition that the first amendment ... protects [a person's] right to kick and rock a video 
tive enforcement should be obvious where the political context suggests that a particular idea, far from being so diffuse and open as to be unrecognizable, is actually being suppressed as unpopular or disfavored by the judge.

A much more common instance of Millian nonspeech involving the police, though often adjudicated as protected "low" speech, is that of directing streams of epithets, sometimes for remarkably prolonged periods of time, at an arresting or investigating police officer. Typically, the speaker is indignant, for reasons that are only rarely ascertainable from the judicial opinion, at the prior arrest of himself or a friend or relative. ${ }^{100}$ One suspects that, in some of the cases, the motivation is simply the inconvenience associated with being arrested. Often, the purported speech is associated with a physical disturbance or resistance to arrest. Sometimes a crowd gathers. In a noteworthy proportion of the cases, the speaker appears to have been drinking immoderately. Despite perhaps even an intent to offend, and the absence of any social idea being communicated, ${ }^{101}$ the purported speech is often judicially protected as free speech, ${ }^{102}$ the disorderly conduct or breach of

game to retrieve fifty cents." Friedman v. Village of Skokie, 763 F.2d 236, 239 (7th Cir. 1985). In this case, the coin return had been welded inoperable and a no-refund policy instituted. Cohen was not mentioned, despite the obvious possibility of arguing for a largely emotive, and perhaps efficacious, "expressive" protest over a legitimate or imagined "grievance." Apparently, no property was damaged or threatened, and mere words would not have sufficed, under the circumstances. See id. at 237. If it turned out that Mr. Friedman did not literally speak in the course of having "attracted the attention of 20 to 30 people who looked on," ibid., it must be pointed out that constitutionally protected nude dancers need not keep up a monologue.

${ }^{100}$ It is difficult to envision the typical defendant as exercising autonomy in the literal form of Kantian legislation. See Kant, The Fundamental Principles of the Metaphysic of Ethics 38, 47, 52 (Manthey-Zorn ed. 1966).

tot Occasionally, a brief, unelaborated reference to the race of one or more of the officers is made. See, e.g., State in re W. B., 461 So. 2d 366, 368 (La. Ct. App. 1984). A coherent focus on the unjustness of "the system" would also help the defendant in Millian terms.

102 When such results are reached, the most typical rationale is that the police are or should be inured to abusive language, that they did not in fact react to the verbal provocation, and that they are paid to not be provoked and are under a legal duty in that regard. The case is therefore held not to fall within the scope of the "fighting words" exception laid down in Chaplinsky v. New Hampshire, 315 U.S. 568 (1942). Sometimes the strand of the Chaplinsky test focusing on the tendency of the language to inflict injury drops out of the analysis entirely. See, e.g., Harbin v. State, 358 So. 2d 856 (Fla. Ct. App. 1978); Rutzick, note 86 supra, at 22-27. Police restraint or indifference, however, does not add social content to the prior "speech." Occasionally, the invective is defended on a theory of the beneficial effects of catharsis. See, e.g., Redish, note 22 supra, at 626. While theories of catharsis or of "blowing off steam" in various contexts have a long and distinguished intellectual pedigree, the experimental support for such theories is limited at best. See J. Goldstein, Aggression and Crimes 
peace charge dismissed, and any "reasonably necessary" force used physically to resist the "illegal" arrest immunized.

An example, selected for the moderation, and not the extremity, of its facts, would be the case of State $v$. Montgomery. ${ }^{103}$ The appellant in Montgomery initiated the incident by loudly shouting a series of profanities, for example, "fucking pigs, fucking pig ass hole," 104 at 10:50 P.M. on a cold February night in downtown Seattle as the two targeted police officers were passing by on patrol in their car. When the police stopped to investigate, the appellant, who was eventually charged with possession of marijuana, continued in a similar linguistic vein. Eventually, it was determined that a recent drinking citation had left the fifteen-year-old appellant irate.

Despite repeated attempts to settle the appellant down, he continued to express himself loudly. Eventually a crowd gathered, which, though sizable enough to block the sidewalk, was not itself threatening or hostile. The appellant did not physically threaten the officers and was not carrying a weapon. Largely because of the sidewalk blocking, the appellant was, after a total of about five to ten minutes, arrested and charged with disorderly conduct and possession of a controlled substance.

On appeal, the convictions for disorderly conduct and for possession of marijuana were reversed on free speech grounds, ${ }^{105}$ with the court citing Cbaplinsky and Cohen and determining that the appellant's conduct deserved moral, but not legal, "censure and rebuke."106 The majority, unmoved by a dissenter's observation that "I fail to see that the 'freedom of speech' contemplated by the First Amendment has anything whatsoever to do with this case," 107 in-

of Violence $36,48,50,53,55,164(1975)$. It is certainly equally plausible to suppose that tolerating, if not actually rewarding, prolonged screaming at police officers legitimizes or encourages such behavior. In any event, this kind of theorizing would not seem to fall within the special competence of the judiciary.

${ }^{103} 31$ Wash. App. 745, 644 P.2d 747 (1982).

${ }^{104}$ Id. at $747-48,644$ P.2d at 748-49.

${ }^{105} I d$. at 760,644 P.2d at 756 .

${ }^{106}$ Ibid. Courts that reverse misdemeanor convictions on this kind of analysis often seek, at least rhetorically, to have it both ways. In one case, the conviction was reversed, but the defendant was solemnly informed that the special restraint required of the police "does not give the public a right to abuse a police officer." People v. Justus, 57 Ill. App. 3d 164, 167, 372 N.E.2d 1115, 1118 (1978). Presumably, a constitutional right is indeed some sort of a right.

10731 Wash. App. at 761, 644 P.2d at 757. 
stead noted the "commonplace" nature of the language employed. ${ }^{108}$

The logical centerpiece of the majority's own independent analysis of the issues noted that ${ }^{109}$

were the use of the invectives and vulgarisms used by the defendant to be held to be grounds for arrest, a number of professional tennis players and other public figures in sports and entertainment would be subject to arrest for their language, oft repeated.

Shrinking from this disturbing prospect, the court in effect constitutionalized its own weighting of the competing interests involved. Because there are some sound, practical reasons for not arresting tennis players, free speech must be involved. ${ }^{110}$

But it is not a mere verbal quibble to distinguish, for Millian value or free speech purposes, between the proposition that fifteenyear-olds, including the speaker, should be permitted publicly to drink or to smoke marijuana, and the almost purely emotive expressions of a negative attitude, of some sort, toward one's own arrest. If no particular grounds for concluding that the original arrest was unfair or discriminatory or arbitrary or illegitimate are given, we are left merely with a negative attitude toward one's own arrest, in particular, principle aside. Verbalizing merely this attitude does not rise to the level of a recognizable attempt to convey or express a social idea in the relevant sense. ${ }^{111}$ If a social idea is not present, the fact that the target of verbal abuse did not or, if reasonable, would

${ }^{108} I d$. at $756 \mathrm{n} .2,644$ P. $2 \mathrm{~d}$ at $754 \mathrm{n} .2$. Courts rarely pause to inquire whether there may be any connection between the increasing frequency of "reprehensible and disgraceful" language and their own increasing inclination to protect it on free speech grounds. See id. at 760,644 P.2d at 756.

109 Ibid.

${ }^{110}$ Perhaps part of the problem is that affirming a disorderly conduct or breach of peace conviction involves at least some modest cost to the particular, identifiable individual defendant, whereas on the other side of the ledger, a presumably desensitized police officer aside, there are only abstract, longer term principles and broader policy considerations, the validity of many of which cannot be rigorously demonstrated.

111 The role in the analysis of the defendant's use of profanity becomes equivocal, particularly in light of the inclination of some courts to focus exclusively on a threat of breach of peace issue, rather than the injurious offensiveness of the language, in Cbaplinsky-type cases. See Gooding v. Wilson, 405 U.S. 518 (1972); see also note 102 supra. There is sometimes the sentiment that the disorderly conduct conviction should be upheld even if, under the circumstances, the defendant had loudly and prolongedly recited nursery rhymes. See, e.g., Morris v. State, 335 So. 2d 1, 2 (Fla. 1976); Mesarosh v. State, 459 N.E.2d 426, 430 (Ind. Ct. App. 1984) (Young, J., concurring).

Yet it is difficult to believe that courts would not take into consideration the saltiness of the language if a loud, extended, socially pointless tirade were directed by a nonthreatening 
not be expected to breach the peace in response is not relevant to the adjudication of the free speech constitutional claim. ${ }^{112}$

\section{CONCLUSION}

Obviously, the notion of "Millian" values has a broader range of operation than its application to the cases here considered. Perhaps they are more readily invoked in the cases noted than in more controversial areas of application, such as the realm of defamation and dissemination of commercial information or misinformation. I meant here only to start a debate, not to conclude it. Understandably, we should be leery about not crediting a free speech claim. But it should be clear that not every principled attempt to limit the expansion of the scope of coverage of the Free Speech Clause reflects a desire to impose orthodoxy or to root out error. While the scope of the Clause should not be artificially circumscribed, as by narrowing its coverage to plainly political issues, neither should it be assumed that the Free Speech Clause has a scope unrelated to its recognizable purposes. ${ }^{113}$

defendant, say, at a nun. We may assume that the nun would not be expected to breach the peace by reacting violently. At least she would be under a recognizable duty not to do so. This scenario is what currently passes for a fiendishly difficult free speech case. While no nun abuse case appears to have been recently decided on appeal, there is the interesting meter maid abuse case of Commonwealth v. Mastrangelo, $489 \mathrm{~Pa} .254,414$ A.2d 54, appeal dismissed, 449 U.S. 894 (1980). In Mastrangelo, the disorderly conduct conviction was upheld despite the lack of evidence of any immediate breach of the peace. The court may have been moved by the fact that the absence of any breach of the peace may have been attributable to the meter maid's having been too frightened to patrol in the area of the defendant's car for a week. The court may also have believed that the injuring, desensitizing process is confined to regular police officers, as opposed to meter maids. Cf. People v. John V., 167 Cal. App. 3d 761, 213 Cal. Rptr. 503 (1985) (sixteen-year-old civilian female target of repeated profane abuse; previous reaction by target included swinging baseball bat at offender and hitting boyfriend instead; speaker's conviction upheld under free speech challenge).

112 The sociological richness of the "fighting words" cases is only hinted at by the examples cited above. See also Wilson v. Attaway, 757 F.2d 1227 (11th Cir. 1985); Bovey v. City of Lafayette, 586 F. Supp. 1460 (N.D. Ind. 1984); aff'd mem., 774 F.2d 1166 (7th Cir. 1985); State v. Beckenbach, 1 Conn. App. 669, 476 A.2d 591 (Conn. 1984); State v. Nelson, 38 Conn. Super. 349, 448 A.2d 214 (1982); Cavazos v. State, 455 N.E.2d 618 (Ind. Ct. App. 1983); State v. Beck, 9 Kan. App. 2d 459, 682 P.2d 137 (1984); State in re W. B., 461 So. 2d 366 (La. Ct. App. 1984); State v. John W., 418 A.2d 1097 (Me. 1980); State v. Groves, 219 Neb. 382, 363 N.W.2d 507 (1985); People v. DuPont, 107 A.D.2d 247, 486 N.Y.S.2d 169 (1985); City of Seattle v. Camby, 38 Wash. App. 462, 685 P.2d 665 (1984), rev'd, 104 Wash. 2d 49, 701 P.2d 499 (1985) (en banc); State v. Yoakum, 30 Wash. App. 874, 638 P.2d 1264 (1982).

${ }^{113}$ Confining the application of the Free Speech Clause to its defensible and proper scope might well vaguely and minimally advantage some persons and disadvantage others in certain contexts, but these effects cannot in principle extend to confiicts between recognizable interest groups, parties, or political forces and causes. Social cause speech remains within the scope of speech and cannot be legitimately exiled as nonspeech. 